\author{
Nicolaas A. Kraft van Ermel
}

\title{
Andrej Sjeptytsky
}

\section{Een problematische Oekraïense held?}

Sinds de val van het communisme ontstond er in Midden- en Oost-Europa vraag naar nieuwe nationale helden. Vaak zijn deze omstreden omdat anticommunisten regelmatig hebben samengewerkt met de Duitsers tijdens de Tweede Wereldoorlog. De Oekraïense aartsbisschop Andrej Sjeptytsky is een voorbeeld van zo'n nieuwe held: aan de ene kant redde hij zo'n 150 Joodse levens, terwijl hij aan de andere kant in 1941 het binnenvallende Duitse leger begroette als 'bevrijders'. Hoe moeten we zulke conflicterende daden beschouwen en wat zegt het feit dat Sjeptytsky vragen oproept over 'goed' en 'fout' in ons geschiedbeeld?

Iedere natie meet zich een eigen verleden aan met eigen historische helden. In Midden- en Oost-Europa ontstond er, nadat het communistische stelsel in de periode van 1989-1991 uiteen was gevallen, behoefte aan andere nationale helden. ${ }^{1}$ Oude helden werden afgestoft en opnieuw op een voetstuk geplaatst. Ook nieuwe helden, die zich in de twintigste eeuw tegen het communisme en/of het Duitse nazisme hadden verzet, kregen een eigen plaats in de nationale canon. De twintigste eeuw was in deze regio echter zo complex, dat verzet tegen het communisme vaak gepaard ging met uitingen van extreem nationalisme, collaboratie met de Duitsers tijdens de Tweede Wereldoorlog of ander onwenselijk gedrag. Dergelijke helden kunnen dus problematisch zijn en laten zien dat onze West-Europese moreel geladen kijk op de twintigsteeeuwse geschiedenis slecht toepasbaar is op Midden- en Oost-Europa. Gezien de situatie na 1989-1991 was de vraag naar dergelijke anticommunistische nationale helden groot. Zo ook in de voormalige Sovjetrepubliek Oekraïne, waar dit verlangen na de politieke omwenteling 
in 2013-2014 alleen nog maar is toegenomen. Graaf Andrej Sjeptytsky (1865-1944) is een van de problematische Oekraïense nationale helden die na de onafhankelijkheid prominent is geworden (zie afbeelding 1). ${ }^{2}$ Wat zorgt ervoor dat Sjeptytsky tot die categorie gerekend kan worden en hoe moeten wij - in WestEuropa-met dit soort postcommunistische natievorming omgaan?

Voordat we op die vragen in kunnen gaan, moeten we eerst een beeld hebben van het leven en werk van Sjeptytsky. Hij was afkomstig uit een Roetheense (protoOekraïense) aristocratische familie uit Galicie. ${ }^{3}$ Deze regio (thans gelegen in het Zuidoosten van Polen en het Zuidwesten van Oekraïne) kende al eeuwenlang een ingewikkelde bevolkingssamenstelling: in de steden woonden vooral Polen, Duitsers

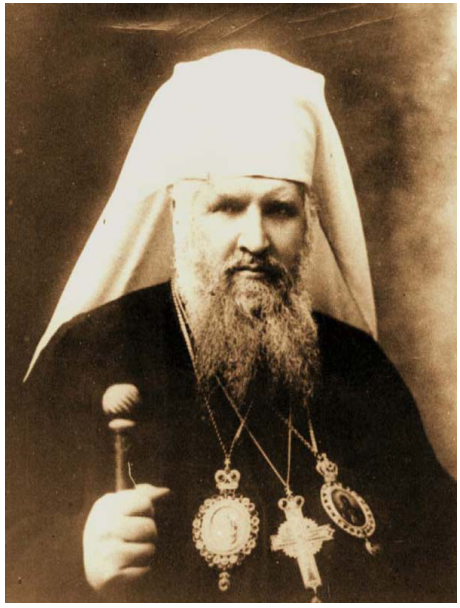

Afbeelding 1. Andrej Sjeptytsky in Rome (1921). Bron: Metropolitan Andrey, Rome, 1921, geraadpleegd 23 februari 2018, https://commons. wikimedia.org/wiki/File:Andrzej_ Szeptycki_(a).jpg. en Joden, op het platteland vooral Oekraïners. Dat gold ook voor Lviv, de belangrijkste stad van de regio: Polen en Joden vormden het gros van de bevolking, Oekraïners vormden slechts een prominente minderheid. ${ }^{4}$ In het westen van Galicië vormden de Polen de grootste bevolkingsgroep, in het oosten de Oekraïners. Het Pools gold daarbij als cultuur-taal en had aanzien, terwijl het Oekraïens slechts als een boerendialect werd gezien. De familie Sjeptytsky was daarom in de negentiende eeuw volledig 'gepoloniseerd' geraakt (Sjeptytsky’s broer Stanisław was een Poolse generaal). Sjeptytsky, Rooms-Katholiek grootgebracht, koos echter voor een andere weg: hij werd geestelijke binnen de Grieks-Katholieke kerk. Deze kerk was ontstaan in 1596 als middel voor de Rooms-Katholieke Poolse koning om de SlavischOrthodoxe inwoners van Galicië aan zich te binden en te poloniseren. Deze kerk is geü nieerd met Rome en erkent de Paus als hoofd van de Kerk en deelt alle belangrijke Katholieke dogma's. Litur-gisch gezien maakt de kerk echter gebruik van de (Slavisch-)Byzantijnse ritus. Van polonisering kwam overigens weinig terecht, maar de kerk werd wel de de facto nationale kerk voor Oekraïners in Galicië. ${ }^{5}$ Sjeptytsky maakte al snel carrière: in 1899 werd hij daarom op voordracht van de Habsburgse keizer Frans-Jozef I (Galicië 
was destijds onderdeel van Oostenrijk) gewijd tot bisschop van Stanislaviv (thans Iva-no-Frankivsk). ${ }^{6}$ Een jaar later werd hij benoemd tot aartsbisschop van Lviv en werd daarmee metropoliet (hoofd) van de Grieks-Katholieke kerk in Galicië. Dat maakte hem dus ook tot een van de belangrijkste geestelijk en politieke vertegenwoordigers van de Oekraïners in Galicië. ${ }^{7}$

Een kort overzicht van de ontwikkelingen in Galicië tussen 1890 en 1944 maakt duidelijk dat Sjeptytsky in die positie tumultueuze tijden doormaakte: de spanningen tussen Polen en Oekraïners namen vanwege nationalisme toe. Bovendien werd Galicië tijdens de Eerste Wereldoorlog door Rusland bezet. Vervolgens viel Oostenrijk-Hongarije uiteen en poogden zowel Polen als Oekraïners Galicië onderdeel te maken van een eigen natiestaat. ${ }^{8}$ Een Oekraïense natiestaat kwam er echter niet en Galicië werd onderdeel van Polen, waar een sterk anti-Oekraïens beleid werd gevoerd. ${ }^{9}$ Het gevolg was dat tijdens het interbellum Oekraïense nationalistische jongeren radicaliseerden en binnen de fascistische en antisemitische Organisatie van Oekraïense Nationalisten (OOeN) met terroristische acties streden tegen wat zij zagen als Poolse bezetting. ${ }^{10}$ In 1939 werd Galicië op grond van het Molotov-Ribbentroppact geannexeerd door de Sovjet-Unie en volgde er wederom anti-Oekraïens, maar ook een antireligieus beleid. De Sovjet geheime dienst, het Volkscomité voor Binnenlandse zaken (NKVD), opereerde met harde hand. ${ }^{11} \mathrm{Na}$ de Duitse inval in 1941 volgde een Duits schrikbewind, met vreselijke gevolgen voor alle Galiciërs, maar met name voor de Joden. In Oekraïne speelden door de Duitsers geronselde Oekraïense milities en (hulp)politie-eenheden niet zelden een rol in de Holocaust. In 1943 organiseerden de Oekraïense nationalisten (inmiddels onder de noemer Oekraïens Opstandelingenleger; OePA) ook nog eens een etnische zuivering op Polen in het noordelijker gelegen gebied Wolynië. ${ }^{12}$ Gegeven de voorname positie van Metropoliet Sjeptytsky in de Oekraïense gemeenschap in Galicië, doet dat de vraag rijzen hoe Sjeptytsky zich in deze situatie verhield tot al dit geweld en of zijn handelen daadwerkelijk de heldenstatus die hem tegenwoordig wordt toegedicht rechtvaardigt. Daarbij leggen we de nadruk op zijn verhouding tot het radicale fascistische nationalisme van de OOeN, zijn relatie tot de Duitse invallers in 1941 en zijn handelen ten aanzien van de deelname van Oekraïners aan massaslachtingen op de Joden tijdens de Duitse bezetting. Overige periodes blijven grotendeels buiten beschouwing, enerzijds omdat de grootste controverses rondom Sjeptytsky in de jaren ' 30 en ' 40 zijn gelegen, anderzijds omdat binnen het bestek van dit korte artikel simpelweg niet alles aan bod kan komen. 


\section{Van Ermel}

\section{Een christelijke natie: Sjeptytsky en het Oekraïense nationalisme}

Metropoliet Sjeptytsky droeg de Oekraïense zaak een warm hart toe. Reeds tijdens de Oostenrijkse periode zette hij zich in voor de rechten van de Oekraïners in Galicië. Dit kwam onder andere tot uiting in zijn inzet voor confessioneel Oekraïenstalig onderwijs en politieke activiteiten gericht tegen de druk tot polonisering door de Poolse elite. Zeker nadat aan het eind van de Eerste Wereldoorlog in zowel Kiev als Lviv Oekraïense republieken werden uitgeroepen, verwelkomde Sjeptytsky deze initiatieven en stond hij positief tegenover het opkomende Oekraïense nationale bewustzijn. Daarbinnen zag hij ook een grote rol weggelegd voor een nationaal bewuste clerus. In Galicië ondersteunde hij ook het streven tot Oekraïens zelfbestuur, gebaseerd op het nationale beschikkingsrecht. ${ }^{13}$

Zijn ideeën gingen niet zo ver dat Oekraïens zelfbestuur of een Oekraïense staat die meer omvatte dan Galicië (Soborna Oekrajina; e e n Oekraïense eenheidsstaat die zowel delen van het voormalige $\mathrm{Habsburgse}$ én Rus is che Rijk besloeg) een doel op zichzelf was (zie) a f b e elding 2). Theologische ideeën bleven de doorslag geven: hij baseerde zijn houding ten opzichte van regimes die over Galicië heersten op de Paulinische theologie. ${ }^{14}$ G e b r u ik make n d van het Bijbelvers "Geef dan wat aan de keizer is aan de keizer, en geef aan God wat God toebehoort" be argumenteerde Sjeptytsky dat een

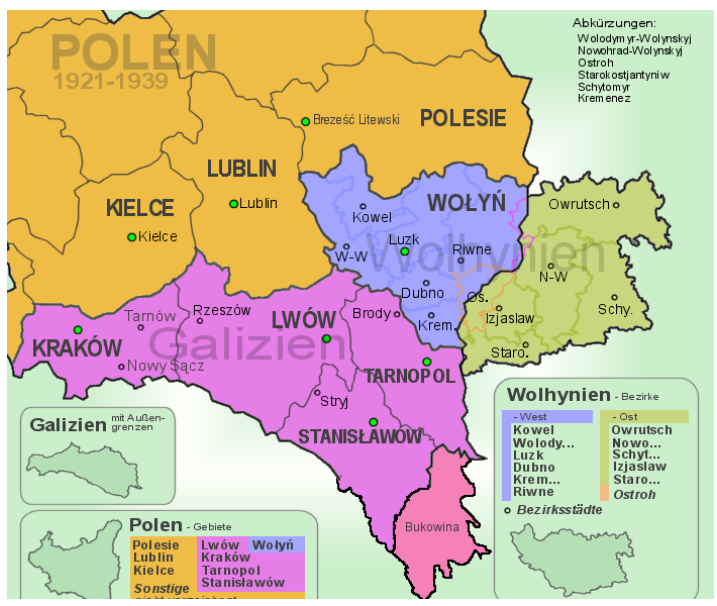

Afbeelding 2. Galicië en Wolhynië tijdens het interbellum. Gedurende het interbellum werd de historische regio Galicië bestuurlijk onderverdeeld onder de Poolse Woiwodschappen (provincies) Kraków, Lwów, Tarnopol en Stanisławów. Het westen van Wolynië vormde het Woiwodschap Wołyn, terwijl het oosten tot de Sovjet-Unie behoorde. Bron: Kai Sören Kotzian, "Polen, Falicien, Wolhynien," Wikimedia Commons, laatst gewijzigd 2005, geraadpleegd 26 juni 2018, https://commons.wikimedia. org/wiki/File:Polen_Galizien_Wolhynien.png. 
Christen gehoorzaamheid verschuldigd was aan het wereldlijk gezag. ${ }^{15} \mathrm{De}$ aard van dit gezag was hierbij niet van belang. Hieraan waren echter wel voorwaarden verbonden. Allereerst diende de staat de jurisdictie van de Kerk in spirituele zaken te erkennen. Ten tweede gold dat een staat enkel legitiem was als diens besluiten rechtvaardig waren en de leiders wijsheid toonden. Volgens theoloog Andrii Krawchuk, die er een uitvoerige studie naar heeft verricht, werd Sjeptytsky's houding ten opzichte van de diverse regimes in Oekraïne dan ook vooral vanuit deze theologische visie gestuurd. ${ }^{16}$ Kort samengevat: hij steunde in principe het streven naar een Oekraïense staat, maar dat betekende niet dat de bestaande orde omver moest worden geworpen.

Die positie bracht Sjeptytsky tijdens het interbellum in conflict met de op fascistische leest geschoeide generatie van jonge nationalisten van de OOeN. Deze pleegden terroristische aanslagen, onder andere een geslaagde moordaanslag op de Poolse minister van Binnenlandse zaken Bronisław Pieracki (1934). Door dergelijke terreurdaden namen anti-Oekraïense maatregelen van de Poolse overheid alleen maar toe. De OOeN ondernam ook acties tegen Oekraïners die zich verzetten tegen de strijd van de OOeN, zoals de moord op gymnasiumdirecteur Ivan Babi (1934). Sjeptytsky kon weinig anders doen dan het politieke geweld - van beide kanten - te veroordelen. ${ }^{17} \mathrm{De}$ OOeN had de totstandkoming van een staat tot een doel verheven dat tegen elke prijs bereikt moest worden. In de Decaloog van de Oekraïense Nationalist (1929) staat onomwonden: "Je zult een Oekraïense staat bereiken, of je zult sterven in de strijd daarvoor", alsook "De vijanden van onze natie zal je slechts met haat en nietsontziende strijd accepteren". ${ }^{18}$ Sjeptytsky veroordeelde deze radicale vorm van Oekraïens nationalisme in diverse pastorale brieven en andere verklaringen. Hij stelde dat het doel zeker niet alle middelen heiligde. Sterker nog, de Oekraïense natie kon zich ofwel houden aan diverse sociale christelijke principes (zoals naastenliefde) ofwel verlagen tot barbarisme (zoals de OOeN reeds had gedaan). Telkens benadrukte hij dat het Oekraïense nationale streven op zichzelf legitiem was, maar dat de wijze waarop de OOeN deze probeerde te realiseren dat niet was. Het Christendom verwierp volgens Sjeptytsky elke vorm van haat, terwijl het radicale nationalisme juist het tegenovergestelde deed. Hij verweet de radicale nationalisten met name dat zij middelbare scholieren voor hun strijd ronselden en daarmee de jeugd corrumpeerden. Bovendien, zo beweerde Sjeptytsky, was het Oekraïense nationale project een collectieve zaak voor alle Oekra-iners en verwierpen de jonge nationalisten juist de ervaringen en ideeën van de voorgaande generaties. ${ }^{19}$ Het viel volgens Sjeptytsky 


\section{Van Ermel}

te prijzen dat jongeren vaderlandsliefde toonden en daar veel voor over hadden, maar hij gaf ook aan dat andermans eigendommen en geluk alsmede andere meningen en overtuigingen geres-pecteerd moesten worden. ${ }^{20}$

\section{Sjeptytsky en het Oekraïense nationalisme tijdens de Duitse bezetting} (1941-1944)

In Galicië begon de Tweede Wereldoorlog feitelijk op 1 september 1939 met de Duitse inval in Polen. Op 17 september bezette de Sovjet-Unie het oosten van Polen, inclusief Galicië. Op 22 juni 1941 viel Duitsland vervolgens de Sovjet-Unie binnen. Wat volgde was een periode van politieke omwentelingen en (politieke) massamoorden. De Oekraïense nationalisten waren inmiddels verdeeld in twee facties: die van de oudere 'gematigde' Andri Melnyk (OOeN-M) en de 'radicale' Stepan Bandera (OOeN-B). Hoewel beide facties collaboreerden met de nazi's, ging OOeN-B daarin het verst. In samenwerking met de Duitse Abwehr (militaire inlichtingen-dienst) waren twee Oekraïense bataljons gevormd: Roland en Nachtigall, welke door de OOeN-B werden gezien als de mogelijke kern van een toekomstig Oekraïens leger. Deze eenheden waren betrokken bij de Duitse bezetting van Lviv. Op 30 juni, na die bezetting, riep de OOeN-B een onafhankelijke Oekraïense staat uit en vormde een regering geleid door Jaroslav Stetsko (1912-1986). Deze verklaring refereerde expliciet aan de Duitsers: "De nieuwgevormde Oekraïense staat zal nauw samenwerken met het Nationaal Socialistische Groot-Duitsland, dat geleid door diens Führer, Adolf Hitler, een nieuwe orde vormt in Europa en de wereld, en het Oekraïense volk ondersteunt zichzelf te bevrijden van Moskovische bezetting". ${ }^{21}$ Vrijwel gelijktijdig vond er een tegen Joden gerichte pogrom plaats. Separaat daarvan vonden er systematische moorden plaats op Joden door SS Einsatzgruppe C. Oekraïense milities van de Stetsko-regering hielpen hierbij. Bovendien had de Stetsko-regering de stad volgehangen met posters die een "Oekraïne voor de Oekraïners" bejubelden. ${ }^{22}$ Er vielen zo'n vierduizend slachtoffers. Een maand later (25-29 juli) vonden er opnieuw pogroms plaats waarbij Oekraiense nationalisten en de burgerbevolking van Lviv (zowel Polen als Oekraïners) een belangrijke rol hadden. Ditmaal vielen er tweeduizend slachtoffers te betreuren. ${ }^{23}$ De regering van Stetsko werd overigens al snel door de Duitsers ontbonden. De oprichting van een Oekraïense staat behoorde immers niet tot de Duitse doelen en de samenwerking met de Oekraïense nationalisten was enkel bedoeld als middel om de bezetting van Oekraïne te vergemakkelijken. ${ }^{24}$ 
Hoe verhield Sjeptytsky zich tot deze gebeurtenissen? Allereerst moet gezegd worden dat tijdens de eerste pogrom Sjeptytsky bezoek kreeg van de bevriende rabbijn Ezechiël Lewin (1897-1941). Lewin had het doel om de invloedrijke Sjeptytsky te informeren over de gebeurtenissen. Terstond bood Sjeptytsky hem een schuilplaats aan, welke door Lewin werd geweigerd, omdat hij bij zijn eigen mensen wilde zijn. Kort na Lewins bezoek vaardigde Sjeptytsky echter een pastorale brief uit waarin hij aangaf dat hij dankbaar was voor de nieuw ontstane Oekraïense staat en de gelovigen opriep om zich aan dit nieuwe wereldlijke gezag te onderwerpen. Een cruciale passage luidde:

Wij begroeten het overwinnende Duitse leger als onze bevrijders van het kwaad. We zullen gepaste gehoorzaamheid geven aan de gevestigde autoriteiten. Wij erkennen dhr. Jaroslav Stetsko als hoofd van het bestuur van de regio West-Oekraïne. ${ }^{25}$

De verklaring stelt ons voor een belangrijke vraag: hoe kan een belangrijk kerkfunctionaris zich, te midden van massaslachtingen die gelijktijdig plaatsvonden, het Duitse leger begroeten als 'bevrijders' en de vorming van een fascistische Oekraïense staat accepteren? Allereerst moet er natuurlijk gewezen worden op Sjeptytsky's eerdergenoemde theologische positie, die elke wereldlijke machthebber, zij het onder voorwaarden, legitiem acht. Daarnaast wordt het 'bevrijdingsaspect' van de verklaring begrijpelijker als men het kortdurende Sovjet-bewind (1939-1941) in West-Oekraïne ogenschouw neemt. Onder dit bewind had de Grieks-Katholieke kerk het zwaar te verduren gehad vanwege het officiële staatsatheïsme en de onderdrukking van Oekraïens nationalisme. De Duitsers draaiden veel van de beperkingen die de Sovjets hadden opgelegd aan de kerk weer te-rug. ${ }^{26}$ De Sovjetbezetting was de eerste kennismaking van West-Oekraïne met totalitair bewind en zo bezien kon het nieuwe gezag haast niet slechter zijn dan het vorige. Het vanaf het einde van de jaren ' 20 in Oost-Oekraïne door de Sovjet-Unie gevoerde anti-Oekraïense beleid speelt mogelijk ook een rol: hier werd bijvoor-beeld de Oekraïense Orthodoxe kerk verboden, onderwijs in het Oekraïens ingeperkt en was er sprake van Russificatie. Ook de door het Sovjetbewind kunstmatig gecreëerde en miljoenen slachtoffers eisende hongersnood in Oost-Oekraïne, de zogenaamde Holodomorvan 1932-1933, maakte de Sovjet-Unie in West-Oekraïne bepaald niet populair. ${ }^{27}$ Bovendien blijft in het ongewisse wat de reactie van de Duitse bezetters zou zijn geweest als Sjeptytsky zich openlijk tegen hen zou hebben gekeerd (hardhandig en gewelddadig optreden tegen de Grieks-Katholieke kerk valt zeker niet uit 


\section{Van Ermel}

te sluiten). ${ }^{28}$

Net als in andere Midden- en Oost-Europese landen maken voorafgaande ervaringen met Sovjetbewind het misschien begrijpelijk waarom Sjeptytsky (en met hem vele andere Oekraïners) de Duitsers als bevrijders zagen, het is aan de andere kant ook zeer naïef te noemen dat er gelijktijdig geloofd werd dat de Duitsers een Oekraiense staat zouden ondersteunen. Toch valt Sjeptytsky's reactie tegen het antisemitische geweld in Lviv zwak te noemen, volgens John-Paul Himka een teken dat Sjeptytsky dit geweld onderschatte. ${ }^{29}$ Publiekelijk heeft Sjeptytsky zich nooit echt uitgesproken tegen de Duitse bezetting. Bovendien heeft Sjeptytsky op z'n minst passieve steun gegeven aan de oprichting van de Oekraïense SS-grenadiersdivisie Galiziën in 1943. Sjeptystky benoemde bijvoorbeeld kapelaans om de divisie van Christelijke begeleiding te voorzien. Ook gaf hij aan zijn coadjutor (hulpbisschop) Josyf Slipy de opdracht tijdens de oprichtingsceremonie een Goddelijke Litur-gie te vieren. ${ }^{30}$ Het is aannemelijk dat Sjeptytsky een gereguleerde militaire eenheid prefereerde boven nationalistische partizaneneenheden of dat de gedachte dat deze eenheid na het einde van de oorlog kon die-nen als kern voor een nationaal Oekraïens leger een rol speelde. ${ }^{31} \mathrm{Al}$ met al levert Sjeptytsky's houding tot de Duitse bezetting een heel gemengd beeld op. Zo blijkt bijvoorbeeld uit een brief van Otto von Wächter (1901-1949), de Duitse gouverneur van Galicië tussen 1942-1944, dat hij Sjeptytsky dan ook, noch als pro-, noch als anti-Duits beschouwde. ${ }^{32}$

\section{Sjeptytsky en de Holocaust: de smet van Kaïns broedermoord}

Was het hierbij gebleven en had Sjeptytsky verder langs deze lijnen geopereerd, dan zou er inderdaad weinig reden zijn om hem een heldenstatus toe te dichten. Het is echter zo dat Sjeptytsky als theoloog én als nationalist zich wel degelijk door morele principes liet leiden. In een brief aan Paus Pius XII van 29-31 augustus 1942 schreef hij dan ook het volgende:

Vandaag is het gehele land het erover eens dat het Duitse regime, misschien nog meer dan het Bolsjewistische regime, kwaad en haast diabolisch is. Zeker al gedurende een jaar is er haast geen dag voorbijgegaan zonder de meest verschrikkelijke misdaden, moorden, roverijen, plunderingen, confiscaties en onrusten. ${ }^{33}$

Zo bezien hadden de Duitsers een van Sjeptytsky's voorwaarden voor een legitieme wereldlijke macht al snel overschreden.

Sjeptytsky restte weinig anders dan zich in te zetten om het moorddadige 
klimaat ongedaan te maken. Hierbij richtte hij zich zowel tot de Duitse bezetters als zijn eigen gelovigen. Hij ging ervan uit dat ieder leven heilig was en dat moord - in geen geval - te rechtvaardigen was. Het verontrustte hem in het bijzonder dat de moorddadigheden niet alleen uitgingen van het Duitse bezettingsregime, maar ook hun grip hadden gekregen op de Oekraïners. Sjeptytsky sprak hierbij duidelijk over een 'bloedschuld. ${ }^{34}$ In een pastorale brief, getiteld Aangaande genade (27 maart 1942) waarschuwde Sjeptytsky voor het herhalen van de misdaad van Kaïn, en riep op zulke zonden met verontwaardiging en afschuw te ontvangen, opdat zij die door deze zonden bevangen waren tot inkeer zouden komen. ${ }^{35}$ Op 21 november 1942 volgde nog een pastorale brief, ditmaal onder de titel Ne Oebi (Gij zult niet doden). De grondgedachte van deze brief was dat moord onder alle omstandigheden een zonde is en dat een moordenaar de 'alomvattende christelijke naastenliefde' verwierp en zich keerde tegen Gods bedoelingen. ${ }^{36}$ Ook de gelovigen werd uitgelegd dat het hier om een zogenaamde 'gereserveerde zonde' ging, waar enkel de metropoliet de opgelegde straf van excommunicatie kon opheffen. Ook riep hij gewone gelovigen op om moordenaars volledig te negeren en hen daarmee tot inkeer te brengen. ${ }^{37}$ De pastorale brief veroordeelde in het bijzonder 'politieke moorden':

Op vreemde wijze maakt men zichzelf en anderen wijs, dat een politieke moord geen zonde is. Alsof politiek een mens ontslaat van diens verplichtingen aan God en een misdaad legitimeert die tegen de menselijke natuur in gaat. Dat is niet het geval. Een Christen is niet enkel in zijn privéle-ven, maar ook in zijn politieke en maatschappelijke leven gebonden aan Gods wet. Een persoon die het onschuldige bloed van zijn vijand, een politieke vijand, vergiet, is net zo'n moordenaar als een mens die dit doet omwille van roverij en verdient dezelfde straf van God en de excommuniatie van de Kerk. ${ }^{38}$

$\mathrm{Nu}$ sprak Sjeptytsky slechts in algemene bewoordingen over moord op politieke gronden. Voor en na de Duitse inval gebruikten Oekraïense nationalisten geweld tegen elkaar en andere Oekrainers die hun radicale politieke agenda niet deelden. Na de Duitse inval kwam daar deelname aan de massamoord op Joden bij. Er zijn echter duidelijke indicaties dat Sjeptytsky zijn brief toch vooral schreef als reactie op de Holocaust. Een eerste aanwijzing is dat er in de brief een sectie gewijd was aan kindermoord. ${ }^{39} \mathrm{De}$ Israëlische historicus Shimon Redlich wijst erop dat Sjeptytsky in 1943 een exemplaar heeft gegeven aan rabbijn David Kahane (1903-1998) die hij in zijn eigen residentie een schuilplaats had geboden. Dit moet gezien worden 


\section{Van Ermel}

als een teken dat de brief gewijd was aan Oekraïense medeplichtigheid aan de moord op Joden. ${ }^{40}$ Bovendien geldt dat de brief reeds in 1942 is verschenen en dat de etnische zuivering op Polen door het Oekraïense Opstandelingenleger in Wolynië pas in 1943 begon.

We moeten ons ook realiseren dat een deel van de pastorale brief, op last van Duitse censors was verwijderd (zie afbeelding 3). Dit deel van de brief verklaarde dat gewone burgers niet het recht hadden 'doodsvonnissen' uit te spreken als straf voor een vermeende misdaad. Dit recht kwam enkel toe aan een overheid en dan ook nog alleen als de misdaad bewezen was en alle beroepsmogelijkheden waren uitgeput. ${ }^{41}$ Dit deel van de brief moet natuurlijk worden opgevat als een verwijzing naar het Duitse bezettingsregime, maar evengoed ook richting Oekraïense nationalisten. Een van de argumenten ter rechtvaardiging van Jodenvervolgingen door Oekraïners te rechtvaardigen was dat Joden hoegenaamd schuldig waren geweest aan de misdaden van de Sovjets tegen Oekrainers en daarom nu dit als rechtmatige straf zouden hebben verdiend. ${ }^{42}$

Meermaals heeft Sjeptytsky ook geklaagd bij de Duitse autoriteiten. Zo heeft hij op 14 februari 1942 een brief gericht aan Heinrich Himmler waarin de metropoliet zich uitsprak tegen het inzetten van Oekraïense politiemensen in antisemitische vernietigingsacties. Deze brief is helaas niet bewaard gebleven, maar verschillende bronnen bevestigen dat deze brief heeft bestaan. ${ }^{43}$ Dit kan zeker een gewaagde stap worden genoemd. Naar 1942): 176-183.

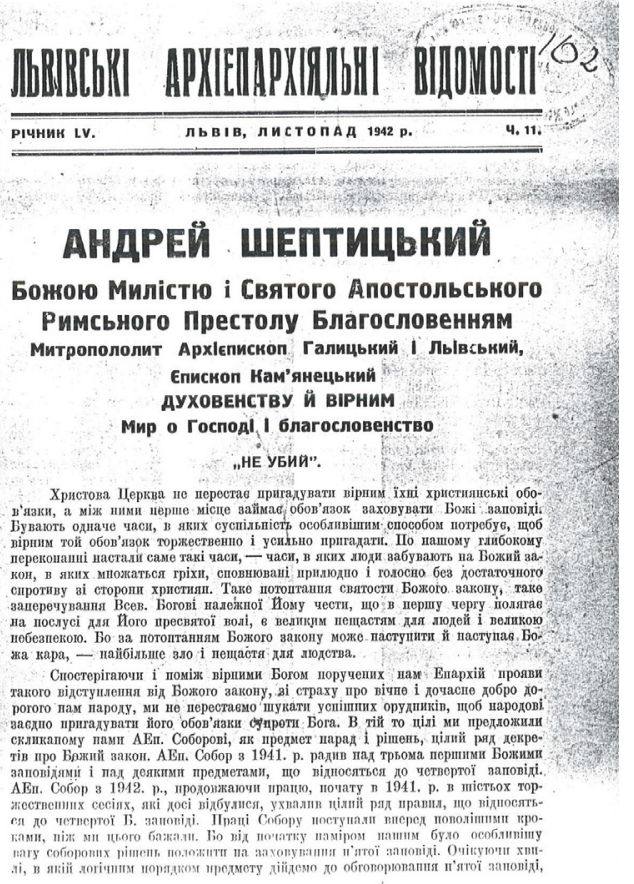

Afbeelding 3. Sjeptytsky's Pastorale Brief 'Gij zult niet Doden'. Bron: Andrej Sjeptytsky, "Ne oebi," Lvivski archieparchijalni vidomosti 55, nr. 11 (november 
Sjeptytsky's eigen zeggen, zou de Duitse officier die Himmlers antwoord bracht hebben opgemerkt dat als Sjeptytsky niet danig op leeftijd zou zijn geweest, hij zou zijn doodgeschoten omdat hij het voor de Joden durfde op te nemen. ${ }^{44}$

Het beeld over Sjeptytsky wordt nog complexer als we zijn reddingsacties in ogenschouw nemen. Sjeptytsky heeft naast de eerdergenoemde rabbijnen Kahane en Lewin, ook rabbijn Kalman Chameides ( $\dagger$ 1942) bescherming en een schuilplaats (aan)geboden. ${ }^{45}$ Daar bleef het niet bij: hij organiseerde een reddingsnet-werk. Hierin speelde Sjeptytsky's broer, Archimandriet Klimenti (1869-1951), een belangrijke rol. Hij was het hoofd van de Grieks-Katholieke monastieke orde van de Studieten, en het was in de kloosters van deze orde dat Joden onderdak vonden. Joden, binnen en buiten de kloostermuren, werden door dit netwerk ook voor-zien van valse doopcertificaten met Oekraiense namen. Veelal betrof het kinderen en in tegenstelling tot vele andere gevallen van Christelijke kloosters die Joden onderdak boden, werden deze Joodse kinderen na de oorlog toevertrouwd aan de zorg van de Joodse gemeenschap en niet gedwongen bekeerd tot het christendom. Deze clandestiene acties getuigen ook van de nodige moed: de Duitsers executeerden immers iedereen die Joden hielp of een schuilplaats aanbood. ${ }^{46}$ Naar schatting zijn er door deze inspanningen ongeveer 150 Joden gered. ${ }^{47}$ Deze inspanningen worden nog indrukwekkender als we ons realiseren dat Sjeptytsky door vergevorderde artritis en ouderdom aan een rolstoel gebonden was en zelfs niet meer zelfstandig kon schrijven. ${ }^{48}$ Hij was bij dit organiseren dus afhankelijk van anderen. Gezien de risico's moet Sjeptytsky in zijn naasten dus een groot vertrouwen hebben gehad.

Voordezeinspanningen zijn ArchimandrietKlimentien een van debetrokken priesters, Marko Stek, door het Israëlische Holocaustherinneringscentrum Yad Vashem onderscheiden als 'Rechtvaardige onder de Volkeren. ${ }^{\text {,9 }}$ De lat voor deze eretitel ligt bijzonder hoog: zo mogen de redders geen geld of andere beloning (bijvoorbeeld in de vorm van bekering tot een andere religie) hebben aangenomen en diende de redding plaats te vinden, terwijl het leven, vrijheid of de persoon van de redder in gevaar was. ${ }^{50}$ Metropoliet Andrej is deze eer niet toegevallen. In een informatiebulletin op de website van Yad Vashem worden Sjeptytsky's inspanningen om Joden te redden wel genoemd en geprezen, maar gelijktijdig eindigt deze met de zin: "Ondanks zijn sympathie voor de Joden, deed Sjeptytsky niets om de Oekraïense nationalisten ervan te weerhouden de kant van Duitsland te kiezen." ${ }^{51}$ Ook vermeldt het bulletin, geheel ten onrechte, dat Sjeptytsky zich niet 


\section{Van Ermel}

uitgesproken zou hebben tegen de terroristische activiteiten van de OOeN. ${ }^{52}$ De argumenten die gebruikt worden om Sjeptytsky de onderscheiding te onthouden hebben te maken met de initiële verwelkoming van het Duitse leger en de steun voor de uitroeping van een Oekraïense staat door de OOeN-B. ${ }^{53}$ Je kunt je heel goed afvragen of dit de interventiepogingen bij de Duitse autoriteiten en het redden van Joden minder heldhaftig maakt. Er bestaat een groeiende groep die betoogt dat Sjeptytsky toch onderscheiden moet worden, zowel in Oekraïne als daarbuiten. ${ }^{54}$ Zo'n stellingname zou het debat over Sjeptytsky kunnen vernauwen. Het risico bestaat dat er alleen nog maar gedebatteerd wordt over deze kwestie, terwijl er allerlei interessante en bredere vraagstukken worden vergeten.

\section{Slotbeschouwing}

De casus Sjeptytsky laat ons allereerst zien dat zelfs mensen met een groot moreel geweten niet onfeilbaar zijn. Juist dat maakt dat hij bij uitstek een 'problematische held' kan worden genoemd. Zoals historicus John Paul Himka het verwoordde: "Slechts zelden komen wij individuen tegen die al wat in hun macht lag deden om de geweldsorgie te stoppen en ertegen te protesteren. Hij was een mens, en als zodanig had zijn tekortkomingen en vooroordelen, maar hij was een mens met een sterk geweten, principes en moed." 55

Ten tweede moet de casus ons doen nadenken over de realiteit van de periode vanaf omstreeks 1921 (vestiging van de post-WO I status quo) en 1953 (Stalins dood) in Midden- en Oost-Europa. In West-Europa schilderen wij de misdaden van de nazi's af als het dieptepunt van de geschiedenis. Bezien vanuit zo'n standpunt is Sjeptytsky duidelijk 'besmet'. Recente historiografische ontwikkelingen over Midden- en Oost-Europa in deze periode laten echter sterke structurele overeenkomsten zien tussen de totalitaire regimes van de nazi's en Sovjets in de regio. Uiteraard botst dat met onze gevestigde opvattingen over het verleden. Zo leidde de publicatie van Timothy Snyders Bloodlands in 2010 tot hevige, vaak emotioneel geladen debatten. ${ }^{56}$ Als we de verschrikkingen van het aan de nazi-bezetting voorafgaande Sovjetregime in ogenschouw nemen, dan valt de opvatting dat de Duitsers bevrijders waren op z'n minst te begrijpen. Dat wil uiteraard niet zeggen dat het ook goed te praten valt. De casus Sjeptytsky is een van de vele die aanleiding geeft de fundamenten van ons geschiedbeeld te overdenken. In dit licht heeft de Duitse historicus Karl Schlögel opgemerkt dat Europa een nieuwe vorm van geschiedschrijving nodig heeft, een die zowel rekenschap geeft van Nazi als Sovjet-misdaden. ${ }^{57}$ Je zou kunnen stellen dat de ingewikkelde 
geschiedenis van onderdrukking door diverse dicta-turen ervoor heeft gezorgd dat in Midden- en Oost-Europa de categorieën van slachtoffer, dader en omstander slechter van elkaar te scheiden zijn dan in West-Europa.

Alles overziende mogen we Sjeptytsky als held prijzen voor zijn inspanningen Oekraïners ervan te weerhouden over te gaan op moord op Joden en zijn eigen inspanningen om Joden te redden. Het problematische karakter van zijn heldendom moet ons doen nadenken over waar nu precies de pijnpunten in de twintigste-eeuwse geschiedenis van Europa liggen. Bovenal geldt dat, hoewel Sjeptytsky een problematische held is, hij nog altijd minder problematisch is dan sommige andere nieuwe helden in Oekraïne, zoals Stepan Bandera (1909-1959) of Roman Sjoechevytsj (1907-1950, een van de leiders van het Oekraïense Opstandelingenleger) aan wiens handen daadwerkelijk onschuldig bloed kleeft.

\section{Noten}

1. De vraag naar dit soort nieuwe helden is intrinsiek verbonden met het opkomende 'postcommunistische nati-onalisme. De kern van dergelijk nationalisme is een slachtofferschapscomplex, waarin de eigen natie geldt als het ultieme slachtoffer van communisme en/of nazisme. Daartegenover worden de nieuwe helden geplaatst, die in feite de positie van voormalige communistische helden opvullen. Zij dienen woede en ressentiment t.o.v. de bestaande slechte (sociaaleconomische) stand van zaken te kanaliseren, waardoor deze door de nieuwe machthebbers gebruikt kan worden. Zie ook: Vladimir Tismaneanu, "After Marx: The Return of Political Myth", in Fantasies of Salvation. Democracy, Nationalism, And Myth in Post Communist Europe (Princeton, New Jersey: Princeton University Press, 1998), 7-8.

2. In Oekraïne is er een overheidsdienst die tot doel heeft propaganda over de Oekraiense geschiedenis te verspreiden. Recentelijk publiceerde dit 'Oekrä̈ense Instituut voor Nationale Herinnering' een aan Sjeptytsky gewijde video op YouTube. Men hoeft geen Oekraïens te verstaan om het hagiografische karakter van deze video te begrijpen. Zie: Ukrainian Institute of National Remembrance, Pro mytropolyta Andreja Sjeptytskoho rozpovidaje svjasjtsjenyk Roman Nebozjoek, 2018, geraadpleegd 15 mei 2018, https:// www.youtube.com/watch?v=UeM9D2Ke6ww.

3. De geschiedenis van het nationale bewustzijn in Oekraïne, Rusland, Wit-Rusland, Litouwen en Polen en bij-behorende terminologie zijn tamelijk ingewikkeld. In feite zijn de Oekraïense, Russische, Wit-Russische en Li-touwse nationale gedachten vanaf de 18e eeuw een claim gaan leggen op de erfenis van het Middeleeuwse vorstendom 'Roes' dat Kyiv als hoofdstad had (882-1240). De term Roetheen (Roesyn) is een oude - in feite niet nationale - identiteit die verwijst naar dit middeleeuwse vorstendom. 


\section{Van Ermel}

Onder de Oost-Slavische bevolking van Galicië was dit de gebruikelijke vorm van zelfidentificatie voor de opkomst van nationale identiteit. Toen het idee van een nationale identiteit zijn intrede deed, kozen zij tussen verschillende richtingen. De Russofielen zochten aansluiting bij het idee van een overkoepelende grote Russische natie terwijl de Oekraïnofielen juist beweerden dat Oekraïners een zelfstandige natie vormden die anders was dan de Russische. Uiteindelijk zou in Galicië de Oekraïnofiele stroming de overhand verkrijgen. Naast deze twee stromingen was er ook nog een kleine minderheid die zich als 'Roetheen' bleef identificeren. Een deel van de Galicische elite koos er juist voor de poloniseren, zij namen de Poolse taal aan en werden RoomsKatholiek. Het leeuwendeel van de familie Sjeptytsky opteerde hiervoor (derhalve noemden zij zich dan ook op z'n Pools Szeptycki). Andrej Sjeptytsky koos echter voor een Oekraïnofiele benadering. De werken van de historici Plokhy en Snyder geven als beste een ingang tot de gecompliceerde kwestie van nationaal bewustzijn in deze regio. Zie: Serhii Plokhy, The Origins of the Slavic Nations: Premodern Identities in Russia, Ukraine, and Belarus (Cambridge, UK; New York: Cambridge University Press, 2006); Serhii Plokhy, Lost Kingdom: The Quest for Empire and the Making of the Russian Na-tion, from 1470 to the Present, 2017; Timothy Snyder, The Reconstruction of Nations: Poland, Ukraine, Lithuania, Belarus, 1569-1999(New Haven, Conn.: Yale University Press, 2003).

4. Deze stad heet in het Oekraïens Lviv, maar is in het Nederlands taalgebied ook bekend onder de Duitse naam Lemberg, de Poolse naam Lwów en de Russische naam Lvov. In 1900 vormden Polen 49.4\%, Joden 26.5\%, Oekraïners 19.9\% en Duitsers 3\% van de bevolking. Armenen waren in Lviv ook een belangrijke minderheid. Voor deze statistieken, zie: Serhi Tsjorny, "Perepys 1900 rokoe: Schidna Halytsjyna”, Natsionalny sklad naselennja Oekrajiny v XX storitsjtsji, Laatst gewijzigd 31 oktober 2010, geraadpleegd 26 juni 2018, https://web.archive.org/web/20101031192201/http://etno. uaweb.org/nsklad/1900-halychyna.html.

5. Voor Sjeptytsky als nationaal leider, zie: Serhii Plokhy, The Gates of Europe: A History of Ukraine (London: Allen Lane, 2015), 238. Er wordt in deze context ook wel gezegd dat Sjeptytsky gezien kan worden als een et-narch (de de facto nationale leider van de Oekraïners in Galicië). Zie bijvoorbeeld: Bohdan Budurowycz, "Sheptyts'kyi and the Ukrainian National Movement after 1914", in Morality and Reality. The Life and Times of Antrei Sheptyts'kyi, ed. Paul Robert Magocsi (Edmonton, Alberta: Canadian Institute of Ukrainian Studies, 1989), 66.

6. Net als Lviv kent deze stad diverse namen: In 1962 werd de stad hernoemd tot IvanoFrankivsk (naar de Oekraïense schrijver Ivan Franko). Daarvoor werd de stad in het Pools Stanisławów genoemd en Stanislaviv in het Oekraïens. Duitsers noemden de stad Stanislau en Russen Stanislavov.

7. Als aartsbisschop van Lviv zetelde Sjeptytsky ambtshalve in het Oostenrijkse Hogerhuis, het Herrenhaus.

8. Andrew Wilson, The Ukrainians: Unexpected Nation, 4th edition (New Haven, CT: Yale University Press, 2015), 127-128; Plokhy, The Gates of Europe, 212.

9. Plokhy, The Gates of Europe, 226-227, 235-240; Wilson, The Ukrainians, 129-132.

10. De notie dat de OOeN fascistisch was is omstreden: de eerste studie over deze

\section{6}




\section{Andrej Sjeptytsky}

beweging, van John Armstrong spreekt van 'integraal nationalisme.'Zijn bronmateriaal was echter vooral afkomstig uit de Oekraïense diaspora in de Verenigde Staten en Canada, waartoe veel gevluchte OOeN-leden behoren. Buiten Oekraïne is het tegenwoordig zeer gebruikelijk om te spreken van een fascistische beweging, zoals bijvoorbeeld gebeurd in recente studies van Grzegorz Rossoliński-Liebe. Cf.: John A. Armstrong, Ukrainian nationalism, 2de dr. (Littleton: Ukrainian Academic Press, 1980); Grzegorz Rossoliński-Liebe, The Fascist Kernel of the Ukrainian Genocidal Nationalism, The Carl Beck Papers in Russian and East European Studies, 4 juni, 2015.

11. Plokhy, The Gates of Europe, 260-263.

12. Dieter Pohl, "Ukrainische Hilfskräfte beim Mord an den Juden," in Die Täter der Shoah. Fanatische Natio-nalsozialisten oder ganz normale Deutsche?, ed. Gerhard Paul, Dachauer Symposien zur Zeitgeschichte 2 (Göttingen: Wallstein Verlag, 2002), 205-234; Karel C. Berkhoff, Harvest of despair: life and death in Ukraine under Nazi rule (Cambridge, Massachusetts: Belknap Press of Harvard University Press, 2004), 64, 285-300.

13. Andrii Krawchuk, Christian Social Ethics in Ukraine: The Legacy of Andrei Sheptytsky (Edmonton: Canadian Institute of Ukrainian Studies Press, 1997), 249-250.

14. De Paulinische theologie, is de invloedrijke theologie die voortkomt uit de brieven van de apostel Paulus die zijn opgenomen in het Nieuwe Testament. Het betreft een alomvattende theologie, die zich onder andere ook uitspreekt over de positie van de kerk in de samenleving. Paulus' brief aan de Romeinen betoogt bijvoor-beeld dat iedere Christen het gezag van de overheid dient te erkennen, omdat er geen ander gezag bestaat dan het door God gezonden gezag. Zie bijvoorbeeld: Rom. 13:1-7 (NBV).

15. Mat. 22:21 (NBV)

16. Krawchuk, Christian Social Ethics, 225-256.

17. Idem., 125-126.

18. Voor deze decaloog, zie: “Dekaloh Oekrajinskoho natsionalista”, OOeN-OePA lehenda sprotyvoe, geraadpleegd 20 februari 2018, http://oun-upa.national.org.ua/documents/ dekalog.html.

19. Krawchuk, Christian Social Ethics, 141 \& 143.

20. Budurowycz, "Sheptyts'kyi and the Ukrainian National Movement," 56.

21. De verklaring is destijds gepubliceerd in meerdere kranten en ook aangepakt. Een foto van zo'n publicatie is opgenomen in: "File:Sam Ukr.Jpg", Wikipedia, november 13, 2015, geraadpleegd 21 februari 2018, https://en.wikipedia.org/w/index. php?title=File:Sam_ukr.jpg\&oldid=690438542.

22. ohn-Paul Himka, "The Lviv Pogrom of 1941: The Germans, Ukrainian Nationalists and the Carnival Crowd", Canadian Slavonic Papers / Revue Canadienne des Slavistes 53, nr. 2-3-4 (2011): 219, 224-225; Per. A. Rudling, The OUN, UPA and the Holocaust: A Study in the Manufacturing of Historical Myths, The Carl Beck Papers in Russian \& East European Studies (Pittsburgh: The Center for Russian and East European Studies, november 2011), 9.

23. "Lvov," United States Holocaust Memorial Museum - Holocaust Encyclopedia, geraadpleegd 21 februari 2018, https://www.ushmm.org/wlc/en/article. 


\section{Van Ermel}

php?ModuleId=10005171.

24. Plokhy, The Gates of Europe, 266-267.

25. Een Engelse vertaling van de verklaring is gepubliceerd als bijlage van: Julian J. Bussgang, "Metropolitan Sheptytsky. A Reassessment," in Polin. Studies in Polish Jewry, ed. Leszek Głuchowski en Antony Polonsky, vol. 21 (Oxford: The Littman Library of Jewish Civilization, 2009), 424-425.

26. Budurowycz, "Sheptyts'kyi and the Ukrainian National Movement", 63-64; Bussgang, "Metropolitan Shep-tytsky", 408; Krawchuk, Christian Social Ethics, 195-198; Hansjakob Stehle, "Sheptyts'kyi and the German Re-gime", in Morality and Reality. The Life and Times of Antrei Sheptyts'kyi, ed. Paul Robert Magocsi (Edmonton, Alberta: Canadian Institute of Ukrainian Studies, 1989), 137-138.

27. Nadat Oost-Oekraïne in 1921 definitief onder Sovjetbewind kwam, stimuleerde de overheid aanvankelijk de culturele ontwikkeling van Oekraïne. Die houding sloeg eind jaren '20 om naar een negatieve houding: (cultureel) nationalisme werd meer en meer gezien als een afwijking van de ware Communistische leer. Deze beleidsverandering vond ongeveer gelijktijdig plaats met Jozef Stalins komst aan de macht. In de jaren '30 was Stalins politiek erop gericht om de Sovjet-Unie te industrialiseren. Om dat doel te realiseren was een drastische verhoging van de landbouwproductiviteit noodzakelijk. Met hardhandige politiek poogde de Sovjetoverheid daarom de Oekraïense boeren toe te laten treden tot zogenoemde 'collectieve boerderijen' (kolchozy). Toen bleek dat deze politiek faalde creëerde de overheid bewust een hongersnood door met geweld zo veel moge-lijk graan uit Oekraïne weg te halen en gelijktijdig de grenzen met de rest van de Sovjet-Unie te sluiten. Vandaag de dag zijn veel zaken aangaande deze hongersnood controversieel: zowel het aantal slachtoffers (variërend van 3-11 miljoen) als de vraag of het een genocide op de Oekraiense natie betrof zijn omstreden. Zie ook: Plokhy, The Gates of Europe, 230-234, 249-255. Recent publiceerde de Amerikaanse journalist Anne Ap-plebaum een uitvoerige studie naar de Holodomor, dat het onderwerp voor het eerst voor een breed westers publiek toegankelijk maakte. Zie: Anne Applebaum, Red Famine: Stalin's War on Ukraine (London: Allen Lane, The Penguin Press, 2017).

28. Het Duitse bezettingsregime aan het oostfront was aanzienlijk gewelddadiger dan in West-Europa. Over het algemeen kan gesteld worden dat er hardhandig opgetreden werd tegen alles dat tegen de Duitse belangen inging. De eerder gememoreerde oprichting van de Stetsko-regering kan als voorbeeld dienen. Omdat de instelling ervan niet in het Duitse belang was werd de regering ontbonden en werden kopstukken van de OOeN-B, waaronder Stepan Bandera gevangengezet. Een ander voorbeeld wordt gevormd door de zogenaamde Intelligenzaktion, gericht tegen de Poolse intelligentsia die geacht werd tegen het Duitse bezettingsregime te zijn. Als onderdeel van deze acties werden hoogleraren van de Jagiellonische Universiteit in Krakau gevangengezet in Duitse concentratiekampen. Er zijn legio andere voorbeelden van dergelijke acties te geven.

29. John-Paul Himka, "Metropolitan Andrey Sheptytsky and the Holocaust", in Polin. Studies in Polish Jewry, ed. Yohanan Petrovsky-Shtern en Antony Polonsky, vol. 26 (Oxford: The Littman Library of Jewish Civilization, 2014), 343. 


\section{Andrej Sjeptytsky}

30. In de Byzantijnse traditie, die de Grieks-Katholieke kerk volgt, wordt gesproken over een 'Goddelijke Li-turgie' waar in de Katholieke traditie het woord 'Eucharistie' gebruikt wordt.

31. Idem., 355-356.

32. De bewuste brief was geadresseerd aan dr. Emil Schumburg (1898-1961), vertegenwoordiger van het Duitse Auswärtiges Ambt bij de Duitse GouverneurGeneraal in Krakau. Zie: Idem., 356.

33. Brief aan Pius XII, 29-31 augustus 1942, zoals geciteerd in: Krawchuk, Christian Social Ethics, 201.

34. Idem., 204.

35. Himka, "Metropolitan Andrey Sheptytsky", 349.

36. Andrej Sjeptytsky, "Ne oebi", Lvivski archieparchijalni vidomosti 55, nr. 11 (november 1942): 178; Een Engelse vertaling van deze pastorale brief is gepubliceerd op: Andrei Sheptyts'kyi, “Thou Shalt Not Kill”, vert. Marco Carynnyk, EHRI Online Course in Holocaust Studies, geraadpleegd 21 februari 2018, https://training.ehri-project.eu/ sites/training.ehri-project.eu/files/EHRI_Ua_D03_Sheptyts\%27kyi_Nov_1942_0.pdf.

37. Sjeptytsky, "Ne oebi", 180.

38. Idem., 179.

39. Idem., 180-181.

40. Shimon Redlich, "Metropolitan Andrei Sheptyts'kyi, Ukrainians and Jews During and After the Holocaust", Holocaust and Genocide Studies 5, nr. 1 (1990): 46.

41. Stehle, "Sheptyts'kyi and the German Regime", 135-136.

42. Volgens Rossoliński-Liebe speelt woede over de vermeende participatie van Joden aan Sovjet-misdaden tegen Oekraïners een belangrijke rol in het ontstaan van antisemitische massamoorden, door Oekraïners verricht. Zie: Grzegorz RossolińskiLiebe, “The 'Ukrainian National Revolution' of 1941: Discourse and Practice of a Fascist Movement”, Kritika: Explorations in Russian and Eurasian History 12, nr. 1 (januari 20, 2011): 101-102.

43. Redlich, "Metropolitan Andrei Sheptyts'kyi", 50, noot 28.

44. Krawchuk, Christian Social Ethics, 234.

45. Bussgang, "Metropolitan Sheptytsky", 413.

46. Redlich, "Metropolitan Andrei Sheptyts'kyi", 47; Krawchuk, Christian Social Ethics, 243-245; Bussgang, "Metropolitan Sheptytsky", 412-413; Himka, "Metropolitan Andrey Sheptytsky", 353.

47. Bussgang, "Metropolitan Sheptytsky", 412.

48. Idem., 401.

49. "Rescue Story Sheptytskyi, Kliment \&Stek, Marko", Yad Vashem, geraadpleegd 23 februari 2018, http://db.yadvashem.org/righteous/family.html?language=en\&itemId=4017786.

50. Zie de vraag 'What are the basic criteria for awarding the title of Righteous' op: "FAQs", Yad Vashem, geraadpleegd 23 februari 2018, https://www.yadvashem.org/righteous/ faq.html\#collapse_2.

51. "Sheptytsky, Andrei", Yad Vashem - The Holocaust Resource Centre, geraadpleegd 23 februari 2018, http://www.yadvashem.org/odot_pdf/Microsoft\%20Word\%20-\%20 6020.pdf. 


\section{Van Ermel}

52. Ibid.

53. Bussgang, "Metropolitan Sheptytsky," 416.

54. De Pools-Joodse wiskundige Julian J. Bussgang spreekt zich bijvoorbeeld uit voor een onderscheiding, dit geldt ook voor de Israëlische historicus Shimon Redlich. Voor een Oekraïens voorbeeld, zie een radio-interview met de Oekraïense etnoloog Olesia Stasiuk. Cf. Shimon Redlich, "My Sheptytsky", Odessa Review, december 4, 2017, geraadpleegd 23 februari 2018, http://odessareview.com/my-sheptytsky/; Bussgang, "Metropolitan Sheptytsky", 401-402; "Andrei Sheptytsky, Righteous Among the Nations and Politician", Ukrainian Jewish Encounter, Laatst gewijzigd 1 september 2017, geraadpleegd 23 februari 2018, https://ukrainianjewishencounter.org/en/andreisheptytsky-righteous-among-nations-politician/.

55. Himka, "Metropolitan Andrey Sheptytsky", 359.

56. Timothy Snyder, Bloodlands: Europe between Hitler and Stalin (London: Bodley Head, 2010). De discussies aangaande Timothy Snyders Bloodlands heb ik in 2017 uiteengezet in een bijdrage aan een congres aan de Universiteit Utrecht. Zie: Nicolaas A. Kraft van Ermel, "Historikerstreit 2.0: The European Consensus on History and the Bloodlands Controversy" (gepresenteerd bij Workshop 1989 and the West. New Perspectives on the End of the Cold War, Utrecht, 2017).

57. Karl Schlögel, "Orte und Schichten der Erinnerung", Osteuropa. Zeitschrift für Gegenwartsfragen des Ostens 58, nr. 6 (2008): 24. 